\title{
Description of growth and body composition of freshwater angelfish (Pterophyllum scalare) by Gompertz model
}

\author{
Carmen Helena Espitia-Manrique ${ }^{1}$, João Batista Kochenborger Fernandes ${ }^{2}$, Nilva Kazue \\ Sakomura ${ }^{3}$, Ángel Andrés Arias-Vigoya ${ }^{2}$, Thiago Matias Torres do Nascimento ${ }^{2}$, Edney Pereira \\ da Silva ${ }^{3}$, Cleber Fernando Menegasso Mansano ${ }^{4^{*}}$ \\ ${ }^{1}$ Universidad Nacional Abierta y a Distancia, Escuela de Ciencias Agrícolas, Pecuarias y del Medio Ambiente, Programa de Zootecnia, Bogotá, \\ Colombia. \\ ${ }^{2}$ Universidade Estadual Paulista, Centro de Aquicultura, Jaboticabal, SP, Brazil. \\ ${ }^{3}$ Universidade Estadual Paulista, Departamento de Zootecnia, Jaboticabal, SP, Brazil. \\ ${ }^{4}$ Universidade Estadual Paulista, Programa de Pós-graduação em Ciência e Tecnologia Animal, Dracena, SP, Brazil.
}

\begin{abstract}
The objective of this study was to describe the growth of freshwater angelfish (Pterophyllum scalare) using the Gompertz model, determining the relative growth and allometric coefficients of body components in relation to body weight and protein weight. Six hundred animals were grown until 233 days of age. Data on chemical composition (water, lipid, protein, and ash) and weight measurements were obtained each 30 days. The Gompertz growth equation was used to analyze chemical allometry and to estimate growth parameters. The relationship between chemical components and body protein was estimated. Protein and body weight increased proportionally, with ash being the earliest nutrient (209.2 days), while lipid deposition occurred later. Linear regression analysis showed an inverse relationship between lipids and body water. This study provided a useful equation to predict the growth, chemical body composition, and rate of nutrient deposition across the life stages of freshwater angelfish. The rates of nutrient deposition as a function of body weight are important to understand the growth process of freshwater angelfish. Thus, mature weight was estimated in $26.14 \mathrm{~g}$. The allometric relationships of body components and deposition rates indicated that protein and body weight are highly correlated across the life stages of freshwater angelfish. The Gompertz equation is a useful tool to describe the growth and body composition of freshwater angelfish.
\end{abstract}

Key Words: allometry, growth curve, ornamental fish

\section{Introduction}

The freshwater angelfish (Pterophyllum scalare) is an ornamental fish native to the Amazon, Orinoco, and Essequibo rivers in South America. It is a popular aquarium species because of its characteristics such as beauty, reproductive behavior, and adaptability to captivity (Sharon et al., 2013). Breeding and improvement of this species have resulted in different strains such as marmorate, gold, siamese, koi, leopard, black, smoke, and clown freshwater angelfish (Ribeiro et al., 2007). However, although several studies on different strains are available, very little is known about the nutrition, growth, and nutritional requirements of

Received: June 12, 2016

Accepted: March 9, 2017

*Corresponding author: clebermansano@yahoo.com.br

http://dx.doi.org/10.1590/S1806-92902017000800001

How to cite: Espitia-Manrique, C. H.; Fernandes, J. B. K.; Sakomura, N. K.; Arias-Vigoya, A. A.; Nascimento. T. M. T.; Silva, E. P. and Mansano, C. F. M. 2017. Description of growth and body composition of freshwater angelfish (Pterophyllum scalare) by Gompertz model. Revista Brasileira de Zootecnia 46(8):631-637.

Copyright ( $\odot 2017$ Sociedade Brasileira de Zootecnia. This is an Open Access article distributed under the terms of the Creative Commons Attribution License (http://creativecommons.org/licenses/by/4.0/), which permits unrestricted use, distribution, and reproduction in any medium, provided the original work is properly cited. this species, factors that are essential for the release of a species on the aquaculture market.

Knowledge about body composition and nutrient deposition rates is important to reduce overall feed waste, improve feed efficiency, and increase profitability (Chowdhury and Bureau, 2009), as well as optimize nutrient conversion into biomass and improve the quality of the final product (Neme et al., 2006; Dumas et al., 2010). Growth and nutrient deposition are accurate parameters to investigate the feed efficiency and nutrient requirements of fish; therefore, to predict the quantitative relationship between nutrient intake and growth and/or nutrient deposition, it is necessary to apply an appropriate model (Belal, 2005).

Mathematical models are analytical solutions of differential equations that can be adjusted to the growth data of animals using nonlinear regression (Sarmento et al., 2006; Thornley and France, 2007; Dumas et al., 2010). Two important factors need to be considered for the selection of an appropriate growth curve model: the possibility of biological interpretation of the parameters and quality adjust (Fitzhugh Jr. and Taylon, 1971; Galeano-Vasco et al., 2014). Several nonlinear mathematical models exist to describe the growth and deposition of body nutrients. One of these 
models is the Gompertz model (Hota, 1994; Marcato et al., 2010; Allaman et al., 2013). An advantage of this model is its sensitivity to estimate the initial values of rapidly growing animals with a very low initial weight, as the example of tadpoles that have a weight of $0.01 \mathrm{~g}$ at the beginning of their lives (Mansano et al., 2012, 2014).

For a better explanation and understanding of the freshwater angelfish growth, the allometric growth method can still be used, which refers to changing different dimensions of body parts that are correlated with the wholebody changes (Gayon, 2000; Garcia et al., 2009). Thornley and France (2007) define allometric growth as the growth of a body part $(x)$ at a different proportional rate from that of the whole body $(y)$. Isometric and allometric relationships based on regression analysis prevail as the best methods to estimate body composition in farmed fish (Dumas et al., 2010). The objective of this study was to describe and predict the growth, chemical body composition, and rate of nutrient deposition in relation to body weight (BW) and protein weight of freshwater angelfish by using the Gompertz and allometry models.

\section{Material and Methods}

The experiment was conducted in Jaboticabal, SP, Brazil (Latitude: -21.2554, Longitude: -48.3224 21 ${ }^{\circ} 15^{\prime} 19^{\prime \prime}$ South, $48^{\circ} 19^{\prime} 21^{\prime \prime}$ West). All procedures followed in the trial were according to the ethical guidelines adopted by the Brazilian College of Animal Experimentation (COBEA) and were approved by the local Ethics Committee on Animal Use (Case no. 8827/15).

Six hundred freshwater angelfish fry (30 days old, $0.2422 \pm 0.055 \mathrm{~g}$ ) were used. The animals were kept in twelve 200-L plastic tanks, 50 fish per tank. The diets were formulated according to Zuanon et al. (2006) and Ribeiro et al. (2007) (Table 1), given at $6 \%$ body weight, four times a day during the grower phase (30-83 days of age) and twice a day during the finisher phase (84-233 days of age). Fifty percent of the tank water was replaced daily. The water quality parameters, such as temperature and dissolved oxygen, were maintained at proper levels and were noted as $28.6 \pm 1.02{ }^{\circ} \mathrm{C}$ and $6.04 \pm 1.33 \mathrm{mg} / \mathrm{L}$, respectively, during the grower phase, while $26.7 \pm 1.47^{\circ} \mathrm{C}$ and $5.93 \pm 1.10 \mathrm{mg} / \mathrm{L}$, respectively, during the finisher phase. The photoperiod consisted of $12 \mathrm{~h}$ light and $12 \mathrm{~h}$ darkness.

Every two weeks, a sample of 20 fish previously starved for $24 \mathrm{~h}$ was randomly chosen. These animals were subjected to body weight determination. The body composition was evaluated monthly. During the first four months, a pooled sample from all tanks was taken for body composition analysis due to the low weight of the individuals. After this period, samples of each tank were selected. The animals were anesthetized with benzocaine $(0.4 \mathrm{~g} / \mathrm{L})$ and euthanized for subsequent analysis. After this procedure, the animals were freeze-dried and ground. The protein, lipid, and ash contents of the samples were determined using the methods described by the AOAC (2000).

The following Gompertz equation was used to describe the growth and nutrient deposition of freshwater angelfish (Gous et al., 1999):

$$
W_{t}=W_{m} \cdot \exp \left\{-\exp \left[-B_{W}\left(\mathrm{t}-\mathrm{t}^{*}\right)\right]\right\}
$$

in which $W_{t}$ is the weight (g) of the animal at time $t ; W_{m}$ is the maturity weight $(\mathrm{g})$ of the animal; $B_{w}$ (g per day) is a rate of maturing parameter; and $t^{*}$ (days) is the time at which the growth rate is at its maximum. The growth rate and nutrient deposition rate were calculated using the first derived of Gompertz equation. The absolute growth rate is:

$$
d W / d \mathrm{t}=B_{W} \cdot \mathrm{W} \cdot \ln \left(W_{m} / w\right)
$$

The classic allometric equation $y=a \times x^{b}$ was linearized using natural logarithm, as described by Thornley and France (2007), and was used for allometric evaluation:

$$
\ln y=\ln a+b \ln x,
$$

in which $y$ is a whole body; $x$ is a body component; $a$ is the normalization constant; and $b$ is the dimension of the allometric parameters. The analysis for obtaining the

\begin{tabular}{|c|c|c|}
\hline Ingredient $^{1}$ & $\begin{array}{l}\text { Grower phase } \\
\text { (up to } 70 \text { days) }\end{array}$ & $\begin{array}{l}\text { Finisher phase } \\
\text { (after } 70 \text { days) }\end{array}$ \\
\hline Fish meal & 130.5 & 135.0 \\
\hline Poultry byproduct meal & 95.7 & 94.0 \\
\hline Soybean meal & 350.0 & 356.7 \\
\hline Corn starch & 50.0 & 60.0 \\
\hline Rice meal & 79.0 & 75.0 \\
\hline Corn & 150.0 & 135.0 \\
\hline Wheat bran & 83.0 & 83.0 \\
\hline Soybean oil & 13.0 & 13.0 \\
\hline Dicalcium phosphate & 10.0 & 3.0 \\
\hline Vitamin and mineral supplement ${ }^{2}$ & 10.0 & 10.0 \\
\hline Vitamin C & 0.3 & 0.3 \\
\hline Kaolin & 28.5 & 35.0 \\
\hline \multicolumn{3}{|l|}{ Composition analyzed } \\
\hline Dry matter (g/kg) & 903.9 & 914.0 \\
\hline Crude protein $(\mathrm{g} / \mathrm{kg})$ & 364.2 & 325.5 \\
\hline Crude energy (kcal/kg) & $4,149.29$ & $4,150.42$ \\
\hline Extract ether $(\mathrm{g} / \mathrm{kg})$ & 63.0 & 60.0 \\
\hline Crude fiber (g/kg) & 40.1 & 39.9 \\
\hline $\operatorname{Ash}(g / k g)$ & 78.0 & 72.9 \\
\hline Calcium (g/kg) & 12.3 & 11.7 \\
\hline Phosphorus (g/kg) & 10.2 & 9.0 \\
\hline
\end{tabular}

Table 1 - Composition $(\mathrm{g} / \mathrm{kg})$ of the experimental diets of freshwater angelfish

${ }^{1}$ Values are reported on a fresh matter basis.

${ }^{2}$ Vitamin and mineral supplement: vitamin A, 500,000 IU; vitamin $\mathrm{D}_{3}, 200,000 \mathrm{IU}$; vitamin $\mathrm{E}, 5,000 \mathrm{IU}$; vitamin $\mathrm{K}_{3}, 1,000 \mathrm{mg}$; vitamin. $\mathrm{B}_{1}, 1,500 \mathrm{mg}$; vitamin $\mathrm{B}_{2}$; $1,500 \mathrm{mg}$; vitamin $\mathrm{B}_{6}, 1,500 \mathrm{mg}$; vitamin $\mathrm{B}_{12}, 4,000 \mathrm{mg}$; vitamin $\mathrm{C}, 15,000 \mathrm{mg}$; folic acid, $500 \mathrm{mg}$; pantothenic acid, 4,000 mg; biotin, $50 \mathrm{mg}$; Hill, $40 \mathrm{~g}$; cobalt, $10 \mathrm{mg}$; copper, $500 \mathrm{mg}$; iron, 5,000 mg; iodine, $50 \mathrm{mg}$; manganese, 1,500 mg; selenium, $10 \mathrm{mg}$; zinc, 5,000 mg; vehicle q.s.q., 1,000 g. 
allometric coefficients were performed using SAS software (Statistical Analysis System, version 9.2). To verify the hypothesis $\mathrm{b}=1$, we applied the Student's t-test $(\mathrm{P}<0.05)$. When $\mathrm{b}=1$, the growth rates $x$ and $y$ are similar and the interval is called isogonic. Otherwise, when $b \neq 1$, the interval is called heterogonic.

The weight and chemical component data were analyzed using the SAS. Once outliers and influential observations were excluded, the normality of errors was verified. Next, nonlinear regression analysis was performed using the PROC NLIN command. Then, using the method of least squares with the Gauss-Newton algorithm, the parameters $\mathrm{A}, \mathrm{B}, \mathrm{K}$, and $\mathrm{M}$ were estimated through the assigned initial values or "priors" taking into consideration the under study species.

\section{Results}

The growth potential of freshwater angelfish was described in relation to maturity weight and whole-body composition. At the end of the trial (233 days), the average body weight (BW) of the fish population was $10.895 \pm 0.804 \mathrm{~g}$. For BW, the asymptotic weight $\left(W_{m}\right)$ was $26.1356 \mathrm{~g}$, the maturation rate $\left(B_{w}\right)$ was $0.008857 \mathrm{~g} /$ day, and $t^{*}$ parameter was 216.93 days, interpreted as the time that the daily growth can reach its maximum value (Table 2 ). The model showed a good fit to the data.

The growth curve of freshwater angelfish weight was estimated using the Gompertz model. The curve generated by the model had a sigmoidal shape and consistency of the biological interpretation of parameter $\mathrm{Wm}(\mathrm{g})$, which was the weight at maturity (Figure 1).

Body weight and body protein were related and indicated that the maximal deposition rate of both was equal at the same time (216 days old) (Table 2 ).

The first derivative of the Gompertz equation showed the protein, lipid, water, and ash deposition rates (Table 3). First, the deposition rate was close to zero for all components, with greater deposition of water. After 60 days, nutrient deposition increased at an accelerated rate until it reached a peak between 216-225 days, followed by self-deceleration. Nutrient deposition was minimal at 550 days of age (Figure 2).

The maximum rate of protein deposition was achieved when the fish had a weight of $9.54 \mathrm{~g}$ and maximum lipid deposition was achieved at a weight of $9.62 \mathrm{~g}$. Fifty percent of the population reached maturity after 258 days for BW, after 256 days for protein, after 257 days for fat, after 245 days for ash, and after 268 days for water.

The allometric relationship between body protein and BW showed an isogonic trend $(b=1.037)$, with protein increasing proportionally to the increase in BW (Table 4). The allometric coefficients, depending on body protein and $\mathrm{BW}$, were similar, but body lipid (BL) and ash (BA) were slightly more correlated with body protein than BW. The performance of the BL about BW was higher, up to 1,105 units of deposited lipid per unit of BW. However, the exchange rate of $\mathrm{BL}$ was increased faster than $\mathrm{BW}$, thus the lipid is the most dynamic macromolecule.

For each body protein unit, there was a tendency to deposit 1.058 units of fat and 0.925 units of water (Table 5 and Figure 3). The growth was isometric for body protein, lipids, and ash in relation to BW (Table 4). Linear regression analysis of body water (BWa) and BW showed a close relationship (Figure 4). In this respect, $3.7426 \mathrm{~g}$ of water was retained per gram of protein deposited.

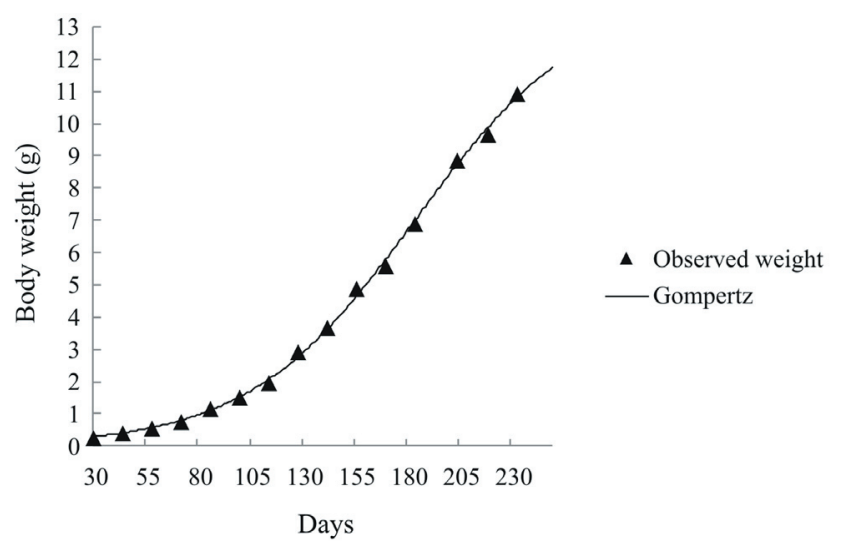

Figure 1 - Body weight of freshwater angelfish fitted by Gompertz model.

Table 2 - Estimates of Gompertz equation parameters for body weight, protein, water, lipid, and ash in freshwater angelfish

\begin{tabular}{|c|c|c|c|c|c|}
\hline \multirow{2}{*}{ Parameter } & \multirow{2}{*}{ Body weight } & \multicolumn{4}{|c|}{ Body component } \\
\hline & & Body protein & Body water & Body lipid & Body ash \\
\hline$W_{m}$ & $26.1356 \pm 2.164$ & $4.5604 \pm 1.347$ & $18.5911 \pm 6.525$ & $2.2871 \pm 0.585$ & $1.1725 \pm 0.365$ \\
\hline$B_{w}^{m}$ & $0.008857 \pm 0.0005$ & $0.00918 \pm 0.002$ & $0.00857 \pm 0.002$ & $0.00959 \pm 0.0017$ & $0.0103 \pm 0.005$ \\
\hline$t^{*}$ & $216.9 \pm 12.001$ & $216.1 \pm 32.367$ & $225.8 \pm 40.155$ & $217.3 \pm 26.818$ & $209.2 \pm 26.869$ \\
\hline $\mathrm{R}_{\text {adj. }}^{2}$ & 0.9983 & 0.9956 & 0.9949 & 0.997 & 0.996 \\
\hline
\end{tabular}

$W$ - asymptotic weight or maturity weight for each component $(\mathrm{g}) ; B$ - rate of maturing parameter for each variable (g/day); $t^{*}-$ time at which the growth rate is maximized fo the variables (days); $\mathrm{R}_{\text {adj. }}^{2}$ - adjusted coefficient of determination. 
Linear regression analysis showed an inverse relationship between the percentage of $\mathrm{BL}$ and $\mathrm{BWa}$. According to the regression coefficients $(y=-1.635 x+$ 80.31 ), each gram of lipid deposited resulted in a decrease of $1.635 \mathrm{~g}$ in BWa (Figure 5).

\section{Discussion}

The Gompertz model has been widely used to analyze growth in many species because of its desirable properties. Moreover, it was estimated that the initial body mass was greater than zero, which reflects the fact that the animal was born with some weight (Santos et al., 2007), being advantageous to describe the growth of young fish together with the parabolic models (Gamito, 1998). The maturity weight is considered an asymptote, which determines a constant condition on a nonlinear model for the chemical

Table 3 - Rate of deposition protein, lipid, water, and ash as a function of age (days) of freshwater angelfish

\begin{tabular}{lcccc}
\hline Age (days) & Protein (g/day) & Lipid (g/day) & Water (g/day) & Ash (g/day) \\
\hline 30 & $0.0009^{1}$ & 0.0003 & 0.0040 & 0.0001 \\
58 & 0.0024 & 0.0010 & 0.0099 & 0.0005 \\
86 & 0.0050 & 0.0023 & 0.0192 & 0.0013 \\
114 & 0.0082 & 0.0040 & 0.0306 & 0.0022 \\
142 & 0.0114 & 0.0058 & 0.0420 & 0.0033 \\
170 & 0.0138 & 0.0072 & 0.0512 & 0.0040 \\
204 & 0.0153 & 0.0080 & 0.0575 & 0.0045 \\
233 & 0.0152 & 0.0079 & 0.0575 & 0.0043
\end{tabular}

Values estimated by first derivative of the Gompertz equation.

Table 4 - Allometric coefficients between body chemical components and body weight in freshwater angelfish

\begin{tabular}{lcccc}
\hline \multirow{2}{*}{ Body component } & \multicolumn{2}{c}{ Coefficient } & \multirow{2}{t}{$\begin{array}{c}\text { t test } \\
\text { Ho:b }=1\end{array}$} & $\mathrm{R}^{2}$ \\
\cline { 2 - 4 } & $\mathrm{a}$ & $\mathrm{b}$ & $*$ & 0.998 \\
Protein & -1.794 & 1.037 & $*$ & 0.999 \\
Lipid & -2.645 & 1.105 & $*$ & 0.999 \\
Ash & -3.306 & 1.022 & $*$ & 0.995 \\
Water & -0.347 & 0.969 & $*$ \\
\hline
\end{tabular}

a - normalization constant; $\mathrm{b}$ - dimension of the allometric parameters; $\mathrm{R}^{2}$ - coefficient of determination.

* Significant at $5 \%$ of probability.

Table 5 - Allometric coefficients of body lipid and body water weight $(\mathrm{g})$ for body protein weight $(\mathrm{g})$ in freshwater angelfish

\begin{tabular}{lcccc}
\hline \multirow{2}{*}{ Body component } & \multicolumn{2}{c}{ Coefficient } & \multirow{2}{t}{$\begin{array}{c}\text { test } \\
\text { Ho:b }=1\end{array}$} & $\mathrm{R}^{2}$ \\
\cline { 2 - 3 } & $\mathrm{a}$ & $\mathrm{b}$ & & \\
\hline Water & 1.322 & 0.925 & $*$ & 0.99 \\
Lipid & -0.739 & 1.058 & $*$ & 0.99 \\
\hline
\end{tabular}

$\mathrm{R}^{2}$ - coefficient of determination.

* Significant at $5 \%$ of probability. composition of a body in a production environment. Parameter $\mathrm{Wm}$ represents the genetic growth potential and the interactions of genes that determined the growth; thus, this asymptomatic measure is a parameter resulting from previous growth stages (Silva et al., 2004).

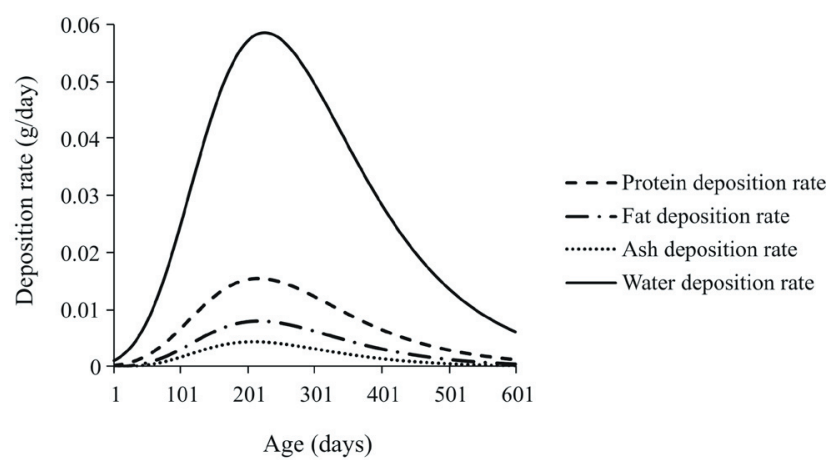

Figure 2 - Gompertz curves of daily deposition rate of body nutrients in the freshwater angelfish.

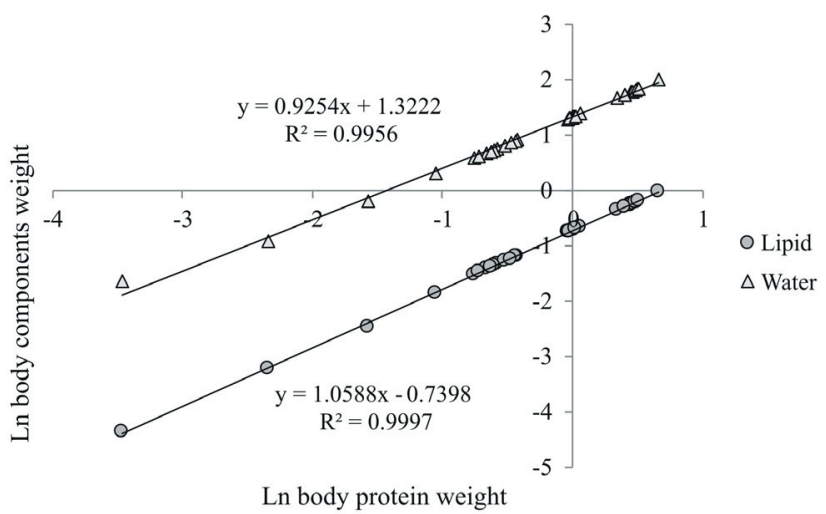

Figure 3 - Allometric relationship between body component weight (lipid and water) and body protein weight in freshwater angelfish.

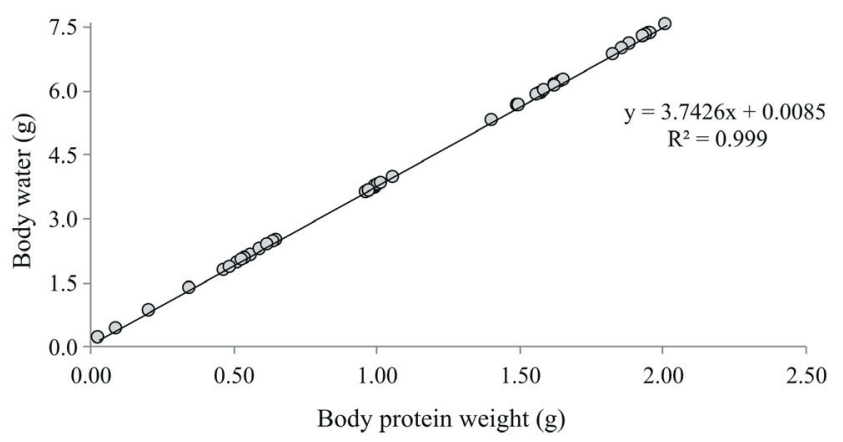

Figure 4 - Allometric relationship between body protein weight and body water in freshwater angelfish. 


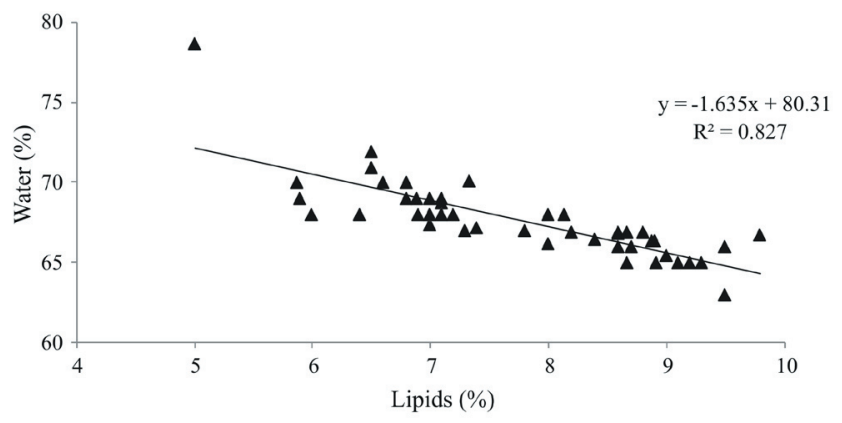

Figure 5 - Linear regression analysis between body water and body lipids in freshwater angelfish.

Body weight and body protein showed a relationship with each other and indicated that their maximal deposition rate was equal at the same time. Similar results have been reported for rainbow trout (Oncorhynchus mykiss), although the environmental factors were different (Dumas et al., 2007). The deposition of body lipid occurred later than that of body protein. Protein deposition is regulated by genetic factors, while lipid deposition depends on environmental and dietary factors (Dumas et al., 2010). Growth rates are highly flexible when environmental interactions influence the size of the animals, with specific growth and mortality being the fundamental factors that characterize the growth of a fish population (Vuori et al., 2006).

After 60 days, nutrient deposition increased at an accelerated rate until it reached a peak between 216-225 days, followed by self-deceleration. According to Dumas et al. (2010), the direction of the growth of individuals demonstrates an initial acceleration phase and is reduced when this individual is in adulthood or during the breeding season for certain species, considering this step as inhibiting the growth phase. Various aquaculture species can grow after reaching maturity, with a large plastic gain (Dumas et al., 2010).

The accuracy of growth models depends on the consistent mathematical description of the relationship between nutrient deposition and weight gain (Dumas et al., 2010). The allometric equations estimate the relationship of body nutrients compared to protein weight or body weight, so the prediction of nutrients in function of protein weight corrects variations in diet-related body fat (Marcato et al., 2010). In this study, the allometric relationship between body protein and BW showed an isogonic trend, with protein increasing proportionally to the increase in BW. This finding can be explained by the fact that protein weight is related to BW. Similar results have been obtained for rainbow trout (Dumas et al., 2007). The deposition of lipid and protein depends on different nutritional factors, such as the balance of essential amino acids and especially the proportion of digestible protein and energy in the diet (Bureau et al., 2002).

The exchange rate of $\mathrm{BL}$ was increased faster than BW; thus, the lipid is the most dynamic macromolecule. A similar intercept and slope has been obtained for rainbow trout (Dumas et al., 2007). Linear regression analysis of BWa and BW showed a close relationship. According to Schmidt-Nielsen (1975) and Jobling (1994), $1 \mathrm{~g}$ of protein is deposited per $3 \mathrm{~g}$ of water. The results obtained in this experiment agree with the study of Dumas et al. (2007), who found an allometric coefficient of 3.894, evaluating nutrient deposition from 66 studies conducted with rainbow trout between 1976 and 2005.

Linear regression analysis showed an inverse relationship between the percentage of $\mathrm{BL}$ and $\mathrm{BWa}$. Similar results have been reported for other fish species such as rainbow trout (Dumas et al., 2007) and alpine trout (Salvelinus alpinus L.) (Lyytikainen et al., 1997).

This study found a linear trend between water and fat for freshwater angelfish (Figure 3). Iles and Wood (1965), analyzing Wood (1958) data, established a close linear relationship between percentage of fat and percentage of water for herring (Clupea harengus); similar results were recorded by Brandes and Dietrich (1953) for muscle fillets from the same species. In addition, it has been found that the relationship is constant under the widely different conditions associated with seasonal cycles of feeding, somatic growth, and gonad maturation (Iles and Wood, 1965).

Emmans (1981) stated that an ideal method to calculate the nutritional requirements and indicate the food intake of an animal during its development is firstly to discover its growth potential. Each animal species has a particular growth curve, which depends on suitable and non-limiting environments. It emphasizes the fact that many aspects, such as maturity, composition, and deposition rates of body nutrients, might interfere with the growth curve. Therefore, the use of mathematical models is necessary to show clearly and with a better precision the growth of these animals according to their age, research, and feeding programs (Gous et al., 1999). Growth models are useful tools that, in addition to evaluating variables within a population, permit to improve the curve points, select desirable traits within a production system, and improve feeding strategies for freshwater angelfish. These findings enhance the understanding of growth prediction equations, chemical 
body composition, and nutrient deposition rates across the life cycle of freshwater angelfish. Nutrient deposition rates as a function of protein weight are important to understand the growth process of freshwater angelfish.

\section{Conclusions}

The Gompertz equation is a useful tool to describe the growth and body composition of freshwater angelfish. The allometric relationships of body components and deposition rates indicates that protein and body weight are highly correlated across the life stages of freshwater angelfish.

\section{Acknowledgments}

To Fundação de Amparo à Pesquisa do Estado de São Paulo (FAPESP) for financial support (2013/25761-4).

\section{References}

Allaman, I. B.; Reis Neto, R. V.; Freitas, R. T. F.; Freato, T. A.; Lago, A. A.; Costa, A. C. and Lima, R. R. 2013. Weight and morphometric growth of different strains of tilapia (Oreochromis $s p$ ). Revista Brasileira de Zootecnia 42:305-311.

AOAC - Association of Official Analytical Chemists. 2000. Official methods of analysis. 17th ed. Association of Official Analysis Chemistry, Gaithersburg, MD.

Belal, I. E. 2005. A review of some fish nutrition methodologies. Bioresource Technology 96:395-402.

Brandes, C. H. and Dietrich, R. 1953. Uber die fettverteilung im korper des herings. Veroff Inst Meeresforsch Bremerhaven 2:109-112.

Bureau D. P.; Kaushik S. J. and Cho C. Y. 2002. Bioenergetics. p.1-59. In: Fish nutrition. 3rd ed. Halver, J. E. and Hardy R. W., eds. Academic Press, San Diego, CA, USA.

Chowdhury, M. K. and Bureau, D. P. 2009. Predicting body composition of Nile Tilapia (Oreochromis niloticus). Asian Fisheries Science 22:597-605.

Dumas, A.; France, J. and Bureau, D. 2010. Modelling growth and body composition in fish nutrition: where have we been and where are we going? Aquaculture Research 41:161-181.

Dumas, A.; Lange, C. F.; France, J., and Bureau, D. P. 2007. Quantitative description of body composition and rates of nutrient deposition in rainbow trout (Oncorhynchus mykiss). Aquaculture 273:165-181

Emmans, G. C. A. 1981. A model of the growth and feed intake of ad libitum fed animals, particularly poultry. p.103-110. In: Computers in animal production. Hillyer, G. M.; Whittemore, C. T. and Gunn, R. G., eds. British Society of Animal Production, London. Occasional Publication, 5.

Fitzhugh Jr., H. A. and Taylon, C. S. 1971. Genetic analysis of degree of maturity. Journal of Animal Science 33:717-725.

Galeano-Vasco, L. F.; Cerón-Muñoz, M. F. and Narváez-Solarte, W. 2014. Ability of non-linear mixed models to predict growth in laying hens. Revista Brasileira de Zootecnia 43:573-578.
Gamito, S. 1998. Growth models and their use in ecological modelling: an application to a fish population. Ecological Modelling 113:83-94.

Garcia, I. F. F.; Perez, J. R. O.; Pereira, I. G.; Costa, T. I. R. and Martins, M. O. 2009. Estudo alométrico dos tecidos da carcaça de cordeiros Santa Inês puros ou mestiços com Texel, Ile de France e Bergamácia. Revista Brasileira de Zootecnia 38:539-546.

Gayon, J. 2000. History of the concept of allometry. American Zoologist 40:748-758.

Gous, R. M.; Moran, E. T.; Stilborn, H. R.; Bradford, G. D. and Emmans, G. C. 1999. Evaluation of the parameters needed to describe the overall growth, the chemical growth, and the growth of feathers and breast muscles of broilers. Poultry Science $78: 812-821$.

Hota, A. K. 1994. Growth in amphibians. Gerontology 40:147-160.

Iles, T. D. and Wood, R. J. 1965. The fat/water relationship in North Sea herring (Clupea harengus), and its possible significance. Journal of Marine Biological Association of the American Fisheries Society 124:345-355.

Jobling, M. 1994. Fish bioenergetics. Chapman and Hall, London.

Lyytikainen, T.; Koskela, J. and Rissancn, I. 1997. The influence of temperature on growth and proximate body composition of under yearling Lake Inari arcticchar (Salvelinus alpinus (L)). Journal of Applied Ichthyology 13:191-194.

Mansano, C. F. M.; De Stéfani, M. V.; Pereira, M. M. and Macente, B. I. 2012. Non-linear growth models for bullfrog tadpoles. Ciência e Agrotecnologia 36:454-462.

Mansano, C. F. M.; De Stéfani, M. V.; Pereira, M. M.; Nascimento, T. S. R. and Macente, B. I. 2014. Morphometric growth characteristics and body composition of bullfrog tadpoles in captivity. Semina $35: 1425-1438$

Marcato, S. M.; Sakomura, N. K.; Fernandes, J. B. K.; Siqueira, J. C.; Dourado, L. R. B. and Freitas, E. R. 2010. Crescimento e deposição de nutrientes nos órgãos de frangos de corte de duas linhagens comerciais. Revista Brasileira de Zootecnia 39:1082-1091.

Neme, R.; Sakomura, N. K.; Fukayama, E. H.; Freitas, E. R.; Fialho, F. B.; Resende, K. T. and Fernandes, J. B. K. 2006. Curvas de crescimento e de deposição dos componentes corporais em aves de postura de diferentes linhagens. Revista Brasileira de Zootecnia 35:1091-1100.

Ribeiro, F. A. S.; Fernandes, J. B. K. and Rodrigues, L. A. 2007. Desempenho de juvenis de Acará-Bandeira (Pterophyllum scalare) com diferentes níveis de proteína bruta na dieta. Boletim do Instituto de Pesca 33:195-203.

Santos, V. B.; Freitas, R. T. F.; Silva, F. F. and Freato, T. A. 2007. Evaluation of morphometric growth curves of tilapia of Nilo (Oreochromis niloticus) strains. Ciência e Agrotecnologia 31:1486-1492.

Sarmento, J. L. R.; Regazzi, A. J.; Sousa, W. H.; Torres, R. A.; Breda, F. C. and Menezes, G. R. O. 2006. Estudo da curva de crescimento de ovinos Santa Inês. Revista Brasileira de Zootecnia 35:435-442.

Schmidt-Nielsen, K. 1975. Animal physiology: adaptation and enviroment. Cambridge University Press, London.

Sharon, G.; Leibowitz, M. P.; Chettri, J. K.; Isakov, N. and Zilberg, D. 2013. Comparative study of infection with Tetrahymena of different ornamental fish species. Journal of Comparative Pathology 150:316-324.

Silva, N. A. M.; Aquino, L. H.; Silva, F. F. and Oliveira, A. I. G. 2004. Curvas de crescimento e influência de fatores não-genéticos sobre as taxas de crescimento de bovinos da raça Nelore. Ciência e Agrotecnologia 28:647-654. 
Thornley, J. and France, J. 2007. Mathematical models in agriculture: quantitative methods for the plant, animal and ecological sciences. 2nd ed. CABI, USA.

Vuori, K.; Strandén, I.; Sevón-Aimonen, M. L. and Mäntysaari, E. A. 2006. Estimation of non-linear growth models by linearization: a simulation study using a Gompertz function. Genetics Selection Evolution 38:343-358
Wood, R. J. 1958. Fat cycles of North Sea herring. Journal du Conseil/ Conseil Permanent International pour l'Exploration de la Mer 23:390-398

Zuanon, J. A. S.; Salaro, A. L.; Balbino, E. M.; Saraiva, A.; Quadros, M. and Fontanari, R. L. 2006. Níveis de proteína bruta em dietas para alevinos de acará-bandeira. Revista Brasileira de Zootecnia 35:1893-1896 